Geologists will probably look to the author to show that, as he has proved the inadequacy of the contractional theory, as usually understood, so he will establish by some calculation, based on probable values of the thickness of rocks affected, and of the changes of density due to hydrothermal action, that the inequalities of the earth's surface are not of greater magnitude than his theory would account for.

\title{
OOREESPONDENTCF.
}

\section{THE SILURIAN ROCKS OF THE LAKE DISTRICT.}

SrR,-My time at present is too much occupied with my official duties to answer Mr. Hicks's letter in the last Geologroal Mag. at any length. Besides, the results of my survey of the Silurian Rocks of the Lake District must be recorded on the maps and in the memoirs of the Government Geological Survey. But I should like to kuow from $\mathrm{Mr}$. Hicks if it is from the fossil evidence or from a careful stratigraphical survey of the rocks of the Lake District that he speaks so confidently of their position. If from the former, there is the danger of arguing in a circle. Certain beds were supposed to be Lower Silurian, therefore the fossils collected from these beds were considered Lower Silurian fossils; and so now these beds are called Lower Silurian, because they contain Lower Silurian fossils. But if a careful stratigraphical survey went to show that these beds were connected with the Upper and not the Lower Silurian, the fossils in these beds would no longer be characteristic of Lower Silurian.

I feel confident that the Stockdale shales of the Lake District are the equivalents of the Tarannon shales of Wales, and the Coniston grits and flags equivalent to the Denbighshire grits and flags, and that the 'Tarannon shales of Wales overlie the Llandovery rocks.

H.M. Geol. Survey, Kendal, July 8, 1876. W. Talbot Aveline.

\section{THE EROSION OF LAKE-BASINS BY GLACIERS.}

SIR,-Some of Mr. Fisher's interesting remarks on the excavatory action of glaciers seem to call for a few words of reply. It is quite true that the. "possibility of the erosion of a great lake by a glacier has not been disproved," and that observations made on the Swiss glaciers now cannot do it; but these observations (and that is all I have ever contended) may render the theory probable or improbable. I doubt whether, in the sense in which we both should use the word, proof would ever in any case be possible. Mr. Fisher, however, seems not to have apprehended the point on which I have always laid most stress in my reasoning (which did not fall within the scope of my last communication to you), viz. that the great majority of Alpine valleys show no tendency to lake-basins, in places near, but above, the present lakes; where the conditions of glacial action must have been as nearly as possible the same as over the area of the basin, that is to say, that if you ascend a valley from the head of a lake, you often find it throughout a true valley of 